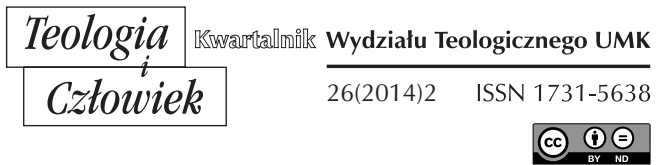

KS. JANUSZ GRĘŹLIKOWSKI*

WARSZAWA

\title{
SPÓR O ODSTĘPSTWO OD WIARY I KOŚCIOŁA
}

DOI: http://dx.doi.org/10.12775/TiCz.2014.019

Niedawne orzeczenia Naczelnego Sądu Administracyjnego (NSA) w sprawie apostazji oraz wewnętrznych przepisów i dokumentów Kościoła, polecające Głównemu Inspektorowi Ochrony Danych Osobowych (GIODO) wydanie proboszczom nakazu odnotowania w kościelnej księdze chrztu aktu apostazji, czyli faktu, że dana osoba wystąpiła z Kościoła katolickiego, choć nie dopełniła kościelnych procedur z tym związanych ${ }^{1}$, budzą zamieszanie, zdziwienie i przyjmowane są, nie tylko przez prawników kościelnych, jako decyzje kuriozalne, niezrozumiałe oraz zagrażające suwerenności i autonomii Kościoła. Stanowią również jednoznaczną ingerencję procedur świeckich $\mathrm{w}$ administrację kościelną. Pozwalają bowiem organom państwowych, w tym wypadku poprzez decyzje GIODO, ingerencję w dokumenty kościelne oraz dają możliwość sprawdzania skarg osób, które wystąpiły z Kościoła.

* Ks. dr hab. Janusz Gręźlikowski - prezbiter diecezji włocławskiej, profesor Wyższego Seminarium Duchownego we Włocławku, oficjał Sądu Biskupiego, profesor nadzwyczajny i kierownik Katedry Historii Kościelnego Prawa Polskiego na Wydziale Prawa Kanonicznego UKSW w Warszawie.

${ }^{1} \mathrm{http}: / /$ orzeczenia.nsa.gov.pl/cbo/search. 
Niezrozumieniu i ewidentnej sprzeczności orzeczeń NSA z wewnętrznym prawem kościelnym dał wyraz bp Wojciech Polak, sekretarz generalny Episkopatu Polski, który stwierdził, że proboszczowie, którzy otrzymali od GIODO taki nakaz, powinni zaskarżyć tę decyzję do NSA². Ks. Józef Kloch, rzecznik Episkopatu Polski, za pośrednictwem swojego profilu na Twitterze zaznaczył, że "strona kościelna nie zgadza się z ingerencją procedur świeckich w administrację kościelną"3.

Decyzje NSA i GIODO spowodowały, że powstało zamieszanie wokół apostazji - odstępstwa od wiary i Kościoła oraz postępowania kościelnego w sprawie formalnego aktu wystąpienia z Kościoła i zapisania tego faktu w księdze chrztu osoby tego dokonującej. Wspomniane decyzje wskazują, że sprawę apostazji, czyli odejścia, wystąpienia z Kościoła mogą regulować przepisy prawa państwowego, a nie kościelne, jak było dotychczas, a Kościół - w zakresie własnej sakramentologii i stosowania swojego wewnętrznego prawa - może podlegać decyzjom państwa. Idąc dalej w komentowaniu tych decyzji, możemy sobie wyobrazić, że państwo może uznać, iż - z jakichś powodów - może decydować nie tylko o tym, kto przestał być katolikiem, ale także o tym, kto nim jest albo kto może nim zostać.

Czy zaistniała sytuacja wynikająca z orzeczeń NSA i decyzji GIODO jest prawidłowa i zgodna $\mathrm{z}$ obowiązującym w Polsce porządkiem prawnym, z Konstytucją i Konkordatem? Czy państwo jest władne i właściwe ingerować w tak oczywiste prawo autonomicznej, suwerennej i równoprawnej wobec niego instytucji, jaką jest Kościół i członkostwo w nim? Jaka jest rola i znaczenie procedur kościelnych określonych w normach prawa kanonicznego i instrukcji Episkopatu Polski w sprawie apostazji? Czy na skutek decyzji NSA i GIODO przestały obowiązywać i Kościół powinien z nich zrezygnować? Jak mają postępować duszpasterze, proboszczowie, mając do czynienia z apostazją - wystąpieniem z Kościoła? Czy powinni wykonać decyzję GIODO nakazującą dokonania adnotacji w księdze chrztów o akcie apostazji konkretnej osoby? To pytania, na które pragnie odpowiedzieć podjęte opracowanie, zapoznając czytelnika z problematyką apostazji, czyli zagadnieniem odstępstwa od wiary i opuszczenia wspólnoty Kościoła. Ukaże ono apostazję w świetle

\footnotetext{
${ }^{2}$ http:/ / kosciol.wiara.pl/doc/1848792.Kuriozalna-decyzja-ws-adnotacji-o-apostazji.

${ }^{3}$ http:/ / wiadomosci.onet.pl/kraj/spor-ws-apostazji-ekspert-zagrozona-jest-autonomia-kosciola/593mv.
} 
norm prawa kanonicznego, kościelne zasady postępowania $\mathrm{w}$ sprawie formalnego aktu wystąpienia z Kościoła, tło i przyczyny sporu i nieporozumień wokół apostazji oraz reperkusje i skutki niedawnego orzeczenia NSA i wydawanych decyzji przez GIODO.

\section{CZYM JEST APOSTAZJA W ŚWIETLE NORM PRAWA KANONICZNEGO}

Z zagadnieniem apostazji mamy do czynienia od zarania chrześcijaństwa ${ }^{4}$. Kiedy chrześcijaństwo stało się religią państwową w Cesarstwie Rzymskim, apostazja stała się przestępstwem państwowym, gdyż stała się zagrożeniem deprawacji społeczeństwa oraz nie sprzyjała interesom Imperium Rzymskiego. Nakazywano więc karać apostatów oraz konfiskować ich majątki. Samo przestępstwo apostazji nie było zagrożone karą śmierci, było zaś nią obwarowane przymuszanie do apostazji ${ }^{5}$.

Według Soboru Laterańskiego IV istotą apostazji było odstąpienie od wiary chrześcijańskiej, porzucenie jej, a ponadto odejście od Boga. Za apostatów należało uważać tych, którzy po przyjęciu chrztu powracali do

${ }^{4}$ Pierwsi chrześcijanie odstępowali od wiary i Kościoła z powodu prześladowań, fascynacji judaizmem czy też pogaństwem. Dlatego w pierwszych wiekach chrześcijaństwa spotykamy wiele wypowiedzi dogmatycznych i dyscyplinarnych Ojców Kościoła (Tertulian, św. Cyprian, Orygenes, Klemens Aleksandryjski, św. Ireneusz, św. Augustyn, św. Ambroży), a także rozporządzeń synodalnych wzywających do wierności wyznawanej wiary, jak też zakazujących i zabraniających chrześcijanom kontaktowania się z Żydami i poganami, łączenia się i uczestniczenia w różnych uroczystościach czy świętach niechrześcijańskich oraz współdziałania w sprawach moralnych, socjalnych lub społecznych. Kościół zakazując chrześcijanom takich kontaktów, myślał, że łatwiej uchroni swoich wiernych przed apostazją. Począwszy od IV wieku, postanowienia prawodawcy kościelnego idą w kierunku ustanawiania zakazów, obwarowanych surowymi sankcjami karnymi uważającymi apostazję za przestępstwo, obok zabójstwa i cudzołóstwa. Nie doprowadziło to jednak do całkowitego wyeliminowania apostazji z życia Kościoła. Od czasów św. Augustyna i św. Hieronima wyraźnie rozróżniano apostazję od herezji, chociaż oba zachowania traktowano jako przestępstwa przeciwko wierze i jedności Kościoła. P. Sadowski, Apostazja i abiuracja - zagadnienie odstępstwa $i$ powrotu do wiary $i$ Kościoła, „Studia Diecezji Radomskiej” 8 (2007), s. 247-249.

${ }^{5}$ Prawny termin apostazji, jako odejście od Kościoła, pojawił się dopiero w roku 426 w konstytucji Teodozjusza II i Walentyniana III, a następnie w Kodeksie Teodozjańskim i Justyniańskim. Zob. P. Sadowski, dz. cyt., s. 250. 
uprzednio wyznawanej religii ${ }^{6}$. Sobór ten przyznał sędziom kościelnym dość dużą arbitralność w karaniu za apostazję ${ }^{7}$. Papież Bonifacy VIII (1294-1303) natomiast nakazał, aby przestępstwo apostazji było karane tak samo jak przestępstwo herezji. Zaowocowało to spadkiem bezpośrednich rozważań i normatywnych dyspozycji w stosunku do apostazji, toteż w ustawodawstwie od końca XIII wieku aż do XVIII stulecia nie pojawiają się specjalne normy, które wprost dotyczyłyby problemu apostazji. Powrócono do nich w okresie odżywania ateistycznych, deistycznych, modernistycznych, naturalistycznych i panteistycznych poglądów na świat. Wtedy papież Pius IX (1846-1878) w konstytucji Apostolicae Sedes z 1869 r. ustanowił karę ekskomuniki latae sententiae na wszystkich chrześcijan dopuszczających się apostazji ${ }^{8}$.

Kodeks prawa kanonicznego z 1917 r. za czyn apostazji nakładał karę ekskomuniki ${ }^{9}$. Przy czym stosował różną terminologię: apostasia a fide (kan. $985 \mathrm{nr} 1$ ), a fide Christiana (kan. 1325 § 2; kan. 2314 § 1), apostasia (kan. $1453 \S 1$ ) oraz apostasia a fide catholica (kan. $646 \S 1$ n. 1; kan. 2314 § 1). Ta różnorodność terminologii pociągała za sobą różnorodność określeń apostazji, od całkowitego odstąpienia od wiary chrześcijańskiej po uprzednio przyjętym chrzcie po odstąpienie od wiary katolickiej ${ }^{10}$. Za uporczywe trwanie $\mathrm{w}$ apostazji, mimo upomnienia, ustawodawca kościelny przewidywał różne kary ${ }^{11}$.

Zgodnie z kan. 751 obecnie obowiązującego kodeksu prawa kanonicznego apostazją jest całkowite porzucenie wiary chrześcijańskiej, dokonane przez osobę ochrzczoną czy też do Kościoła katolickiego

${ }^{6}$ L. Winowski, Stosunek średniowiecznej Europy do obcych - innowierców, „Prawo Kanoniczne" 4 (1961), nr 1-2, s. 632-633.

7 Por. J. Syryjczyk, Apostazja od wiary w świetle przepisów kanonicznego prawa karnego. Studium prawno-historyczne, Warszawa 1984, s. 219.

8 Zob. P. Gasparri, Codicis Iuris Canonici Fontes, t. III, nr 552, Romae 1933, s. 25.

${ }^{9}$ Kan. 2314 § 1 KPK z 1917 r.

${ }^{10}$ Por. J. Syryjczyk, Apostazja od wiary..., s. 223-224.

${ }^{11}$ Takie jak: pozbawienie beneficjum, godności, pensji, urzędu lub innego obowiązku w Kościele oraz infamię prawną. Natomiast duchowni po powtórnym upomnieniu byli deponowani. Zapisanie się do sekty akatolickiej powodowało infamię, a duchowni po bezskutecznym upomnieniu byli degradowani. Dotknięci infamią prawną nie mogli być dopuszczeni do święceń ani też nie mogli wykonywać władzy wynikającej ze święceń, chyba że po uzyskaniu dyspensy zarezerwowanej Stolicy Apostolskiej. Por. P. Sadowski, dz. cyt., s. 251. 
przyjętą $^{12}$. Istotnym elementem apostazji jest więc całkowite porzucenie wiary chrześcijańskiej, tak że apostacie nie może przysługiwać miano chrześcijanina $^{13}$. Stąd obecne prawo kanoniczne mówi jedynie o apostazji a fide ${ }^{14}$. Apostazja - jak zauważa zmarły niedawno ks. prof. Jerzy Syryjczyk - „powstaje nie tylko przez porzucenie wiary chrześcijańskiej, ale także przez zaprzeczenie prawdom fundamentalnym lub istotnym dla tej religii. Ma to miejsce $\mathrm{w}$ wypadku odrzucenia Objawienia Bożego, jak i w sytuacji zaprzeczenia istnieniu Boga lub Bóstwa Chrystusa. Przestępstwo konstytuuje więc odstąpienie od tych prawd wiary chrześcijańskiej, bez których nie można mówić, że religia jest jeszcze chrześcijańska"15.

Tak rozumiana apostazja a fide polega na zewnętrznym i jednocześnie wewnętrznym odstąpieniu od wiary. Stąd popełnienie przestępstwa apostazji nie dokonuje się wyłącznie aktem wewnętrznym, ale również wymaga aktu zewnętrznego, czyli formalnej deklaracji, czy to słowem, pismem, czy też czynem. Nie może być przestępstwem naruszenie ustawy tylko aktem wewnętrznym. Naruszenie wewnętrzne, które dotykałoby tylko świata myśli i pragnień, nie ukazując się na forum zewnętrznym, nie może być potraktowane jako przestępstwo. Naruszenie to, aby było zewnętrzne, nie musi być publicznym ${ }^{16}$. Przestępstwa apostazji nie stanowi więc indyferentyzm religijny. „Nie może też być uważany za apostatę chrześcijanin, który nie wypełnia praktyk religijnych albo w stosunku do wiary jest całkowicie obojętny czy ją zaniedbuje. Taki ochrzczony chrześcijanin, dopóki nie okaże swego zamiaru porzucenia wiary, może być uważany tylko za złego chrześcijanina. Również tylko zewnętrzne porzucenie wiary $\mathrm{z}$ jednoczesnym jej utrzymaniem $\mathrm{w}$ zakresie wewnętrznym nie konstytuuje przestępstwa apostazji, chociaż w zakresie zewnętrznym należy sądzić, że sprawca jest apostatą. Podstawą takiego twierdzenia jest fakt, że na podstawie zewnętrznego zachowania się,

${ }^{12}$ Por. J. Syryjczyk, Kanoniczne prawo karne. Część szczegótowa, Warszawa 2003, s. $19-20$.

${ }^{13}$ J. Krzemieniecki, Przestępstwo apostazji, herezji $i$ schizmy w Kodeksie Prawa Kanonicznego, kanon 2314 i jego praktyczne zastosowanie, „Ateneum Kapłańskie” 40 (1937), s. $34-47$.

${ }^{14}$ Zob. kan. 1364 § 1 KPK.

15 J. Syryjczyk, Kanoniczne prawo karne..., s. 21.

${ }^{16}$ Zob. T. Pawluk, Prawo kanoniczne wedtug kodeksu Jana Pawta II, t. 4: Doczesne dobra Kościoła. Sankcje w Kościele. Procesy, Olsztyn 1990, s. 123. 
które świadczy o porzuceniu wiary, sądzi się o jej porzuceniu również w zakresie wewnętrznym"17.

Kanoniczne prawo karne wskazuje, że do zaistnienia przestępstwa apostazji oprócz skutku, jakim jest obiektywne odstąpienie od wiary chrześcijańskiej, wymagana jest duża wina sprawcy. Popełnienie apostazji wymaga jednocześnie poczytalności, a więc musi to być działanie wolne i świadome, a popełniający to przestępstwo winien działać z winą umyślną. Jeżeli było niezawinione, to trudno wtedy mówić o porzuceniu wiary chrześcijańskiej, czyli apostazji ${ }^{18}$. Możemy powiedzieć, że akt wystąpienia z Kościoła jest skuteczny wówczas, gdy deklaracji zewnętrznie towarzyszy wewnętrzne przekonanie i pragnienie zerwania kościelnej wspólnoty wiary, sakramentów i władzy pasterskiej.

Zgodnie z kan. 1364 § 1 KPK odstępca od wiary, heretyk lub schizmatyk podlega ekskomunice wiążącej mocą samego prawa (latae sententiae). Jeżeli chodzi o osobę duchowną, to jeżeli domaga się tego długotrwały upór lub wielkość zgorszenia, można dołączyć także inne kary, nie wyłączając wydalenia ze stanu duchownego ${ }^{19}$. Ekskomunika to najcięższa kara kościelna polegająca na wyłączeniu chrześcijanina ze współuczestnictwa z wiernymi. Praktyczne skutki zastosowania ekskomuniki latae sententiae, gdy przestępstwo jest tajne, w przypadku apostaty to: „zakaz udziału posługiwania w sprawowaniu Ofiary eucharystycznej lub w jakichkolwiek innych obrzędach kultu, sprawowaniu sakramentów i sakramentaliów oraz przyjmowania sakramentów, sprawowania kościelnych urzędów lub posług albo jakiegokolwiek innego zadania, bądź wykonywania aktów rządzenia"20. Jeżeli ekskomunika została wymierzona lub deklarowana, a więc mamy do czynienia z publicznym przestępstwem apostazji, to ekskomunikowany „powinien być usunięty albo czynność liturgiczna powinna być przerwana, chyba że przeszkadza temu poważna przyczyna; nieważnie podejmuje akty rządzenia, nie może korzystać z przywilejów wcześniej mu udzielonych; nie może ważnie otrzymać w Kościele godności, urzędu lub innego zadania; dochody z tytułu godności, urzędu, jakiegokolwiek zadania i posiadanej ewentualnie

${ }^{17}$ J. Syryjczyk, Kanoniczne prawo karne..., s. 21.

18 Zob. Tamże, s. 22; por. P. Sadowski, dz. cyt., s. 252.

${ }_{19}$ Zob. kan. $194 \S 1$ n. 2; 1336 § 1 n. 1 , 2 i 3 oraz § 2 KPK; por. P. Sadowski, dz. cyt., s. 253.

${ }^{20}$ Kan. 1331 § 1 KPK. 
w Kościele pensji nie stanowią jego własności"21. Nadto kto publicznie odstąpił od wiary katolickiej lub wspólnoty z Kościołem, mocą samego prawa zostaje usunięty z urzędu kościelnego. Względem zaś duchownego można zastosować zakaz lub nakaz przebywania na określonym miejscu lub terytorium, pozbawienie władzy, urzędu, zadania, prawa, przywileju, uprawnienia, łaski, tytułu i odznaczenia ${ }^{22}$. W myśl kan. 1338 $\S 2$ KPK apostaty nie można ukarać pozbawieniem stopni akademickich. Natomiast w sytuacji długotrwałego uporu i wielkiego zgorszenia duchownego można wydalić ze stanu duchownego ${ }^{23}$.

Analizując aktualnie obowiązujące przepisy kanonicznego prawa karnego odnoszące się do apostazji, należy zauważyć, że pojęcie „apostazja" nie jest tożsame $\mathrm{z}$ wystąpieniem $\mathrm{z}$ Kościoła katolickiego formalnym aktem. Przy apostazji nie ma wymogu przyjęcia oświadczenia woli przez kompetentną władzę kościelną. Wymóg taki pojawia się natomiast przy formalnym akcie wystąpienia z Kościoła katolickiego. Wyraźnie o tym mówi komunikat Papieskiej Rady do spraw Tekstów Prawnych z 13 marca 2006 r., który wyjaśnia pojęcie formalnego aktu wystąpienia z Kościoła katolickiego (actus formalis defectionis ab Ecclesia catholica), podając jednocześnie wymogi takiego aktu: 1. wewnętrzną intencję odejścia z Kościoła katolickiego, 2. zewnętrzne wyrażenie takiej intencji, 3. przyjęcie decyzji wystąpienia z Kościoła przez kompetentną władzę kościelną. Tylko wspólne zaistnienie tych trzech okoliczności powoduje skutek prawny $\mathrm{w}$ postaci rzeczywistego zaistnienia formalnego aktu. Tak rozumiane działanie musi być dokonane przez prawnie zdolną do tego osobę w sposób osobisty, świadomy i wolny oraz ujawniony przez zainteresowanego $\mathrm{w}$ formie pisemnej wobec władzy kościelnej (własnego proboszcza lub ordynariusza $)^{24}$. Komunikat zobowiązuje nadto tego, przed kim został taki akt złożony, do zadbania o odnotowanie tegoż w sposób wyraźny w księdze ochrzczonych ${ }^{25}$.

${ }^{21}$ Kan. 1331 § 2 KPK.

${ }^{22}$ Zob. kan. 1336 KPK.

${ }^{23}$ Kan. 1364 § 2 KPK; por. P. Sadowski, dz. cyt., s. 253-254.

${ }^{24}$ Zob. Papieska Rada ds. Tekstów Prawnych, Komunikat z dnia 13 marca 2006 r. (Prot. N. 10279/2006), „Miesięcznik Diecezji Włocławskiej - Kronika” 89 (2006), nr 4, s. 231-233.

${ }^{25}$ Zob. P. Sadowski, dz. cyt., s. 253. 


\section{KOŚCIELNE ZASADY POSTĘPOWANIA W SPRAWIE FORMALNEGO AKTU WYSTĄPIENIA Z KOŚCIOŁA}

Problem apostazji na życzenie zainteresowanego, niezwiązanej z kościelną karą za notoryczne i publiczne manifestowanie odejścia od wiary i Kościoła, to nowe zjawisko w historii Kościoła w Polsce. Danie odpowiedzi na pytanie, jakie są przyczyny i motywy wystąpień z Kościoła, jest zapewne bardzo trudne i złożone, gdyż odnosi się do wewnętrznej decyzji człowieka, traktowania przez niego wiary, Kościoła i swojego życia. Odstępowaniu od wiary i Kościoła sprzyja dzisiaj wyobcowanie ze wspólnoty Kościoła i wiary, mentalność relatywizmu etycznego i źle praktykowanego ekumenizmu, czyli takiego, który charakteryzuje się ,,jałowością rozmów" czy proponowaniem indyferentyzmu i synkretyzmu ${ }^{26}$. Wielu młodym ludziom kościół jawi się dzisiaj jako instytucja zacofana, która wyłącznie sobie przypisuje monopol na prawdę, instytucja, która nie dorasta do swego powołania i nie zasługuje na mandat zaufania, niewiarygodna, zbyt daleko wkraczająca w prywatne życie człowieka, a także w wymiar społeczny i polityczny życia. Wśród przyczyn odpychających od Kościoła podaje się: rygoryzm moralny i fanatyzm w narzucaniu „wyznawanej etyki” innym, moralność seksualną, sprzeciw wobec aborcji i rozwodów małżeńskich, struktury organizacyjne i bogactwo Kościoła. Jako przyczyny, dla których niektórzy młodzi katolicy odchodzą od Kościoła wymienia się: niespełnienie oczekiwań, jakie człowiek pokładał w Bogu, zauroczenie się inną religią lub sektą, kryzys wiary, ignorancję, lenistwo religijne, wyzwolenie się z presji religijnej, chęć życia „na luzie”, niezrozumienie przykazań Bożych, skandalizowanie się postępowaniem niektórych duchownych, znużenie Kościołem, uleganie wzorcom lansowanym przez telewizję, niepowodzenia życiowe, rozczarowania, chęć doświadczenie czegoś nowego, brak dobrej woli ${ }^{27}$.

Zarzuty pod adresem Kościoła, te wymienione i cały szereg innych, stanowiące często powód odstępstwa od wiary i Kościoła niekiedy są prawdziwe, a czasami wypływają z niezrozumienia wiary, struktury i posłannictwa Kościoła. Człowiek, który tak bardzo gorszy się Kościołem, że postanawia go porzucić, powinien zdać sobie sprawę, że już dużo wcześniej doszło do smutnej pomyłki w jego życiu. Polegała ona na zastąpieniu Ewangelii własną, "autorską" wizją chrześcijaństwa i Kościoła,

\footnotetext{
26 Tamże, s. 247-248.

27 Tamże, s. 248.
} 
która ma znikomą liczbę punktów stycznych z duchem Pisma Świętego i nauką Chrystusa. Taka sytuacja musiała w końcu doprowadzić do rozłamu: porzucenia Kościoła, który żyje wiarą inną niż moja. Nie ulega też wątpliwości, że wystąpienie z Kościoła dowodzi braku dojrzałości wyznawanej wiary, braku integralnego spojrzenia na Kościół, nieumiejętności rozróżnienia tego co boskie, a co ludzkie, utożsamiania niektórych członków Kościoła z całym Kościołem ${ }^{28}$.

Ponieważ zjawisko wystąpień z Kościoła w Polsce to rzeczywistość nowa, która pojawiła się od niedawna, dlatego nie było dotychczas jednoznacznej i jednolitej praktyki określającej procedurę postępowania w sytuacji wystąpienia ze wspólnoty Kościoła formalnym aktem. Konferencja Episkopatu Polski postanowiła zatem określić zasady i kryteria występowania z Kościoła katolickiego. Prace nad odpowiednią instrukcją trwały od dłuższego czasu i miały na celu określenie jednolitego postępowania $\mathrm{w}$ takich sytuacjach we wszystkich diecezjach $\mathrm{w}$ Polsce, zgodnie z prawem i stanowiskiem Papieskiej Rady do spraw Tekstów Prawnych ${ }^{29}$. Dokument taki, pt. Zasady postępowania w sprawie formalnego aktu wystapienia z Kościoła, został wydany przez Konferencję Episkopatu Polski 27 września 2008 r. ${ }^{30}$ Wychodzi on naprzeciw pojawiającym się wystąpieniom ze wspólnoty Kościoła, pomaga odróżnić chwilowe i koniunkturalne deklaracje od tego, co prawo kanoniczne nazywa jako świadome i dobrowolne wyłączenie się ze społeczności wiernych, jak też wprowadza jednolite postępowanie $\mathrm{w}$ sytuacji wystąpienia na życzenie ze wspólnoty Kościoła.

W myśl powyższego dokumentu określone oświadczenie woli tylko wtedy może być uznane za akt formalnego wystąpienia z Kościoła, gdy towarzyszy mu wewnętrzna wola katolika składającego oświadczenie, odpowiednio (tzn. w sposób niebudzący wątpliwości) wyrażona na zewnątrz, z zachowaniem wymagań przewidzianych przez prawo ${ }^{31}$.

Aktu odstępstwa, który wywołuje skutki kanoniczne, może dokonać tylko osoba pełnoletnia (kan. 981 i 2 KPK), zdolna do czynności prawnych, w sposób świadomy i wolny (kan. 124-126 KPK), w formie

28 Tamże.

29 www.kai.pl.

30 Konferencja Episkopatu Polski, Zasady postępowania w sprawie formalnego aktu wystapienia z Kościoła, „Miesięcznik Diecezji Włocławskiej - Kronika” 91 (2008), nr 10, s. $870-876$.

31 Tamże, n. 4, s. 871. 
pisemnej, w obecności proboszcza swego kanonicznego miejsca zamieszkania (stałego lub tymczasowego) i dwóch pełnoletnich świadków. Zaleca się, by - jeśli to możliwe - przynajmniej jednym ze świadków był ktoś z rodziców lub chrzestnych odstępcy, którzy towarzyszyli mu kiedyś w przyjęciu do Kościoła ${ }^{32}$.

Skuteczność kanoniczna takiego formalnego aktu wystąpienia z Kościoła uzależniona jest od osobistego złożenia własnoręcznie podpisanego pisma, w którym odstępca wyraźnie przedstawia swoją wolę opuszczenia Kościoła. Oświadczenie winno zawierać dane personalne odstępcy i świadków, motywację oraz dokładne dane dotyczące daty i parafii chrztu wraz z załączeniem świadectwa chrztu. W piśmie powinna być również zawarta informacja o tym, że odstępca dokonuje tego aktu dobrowolnie i ze świadomością konsekwencji, jakie ów akt pociąga za sobą. Nie wywołuje skutków kanonicznych oświadczenie złożone przed urzędnikiem cywilnym lub przesłane do parafii drogą pocztową lub elektroniczną ${ }^{33}$.

Zasady postępowania $w$ sprawie formalnego aktu wystapienia $z$ Kościoła Episkopatu Polski określają szczegółowo postawę i zachowanie duszpasterzy w tego typu sytuacjach. Otóż gdy proboszcz otrzyma wiadomość o zamiarze wystąpienia z Kościoła swojego parafianina, winien w osobistej, pełnej troski i życzliwości rozmowie duszpasterskiej rozeznać przyczyny odejścia od wspólnoty Kościoła oraz z miłością i roztropnością podjąć wysiłki, by odwieść wiernego od tego zamiaru. Dlatego z zasady akt formalnego wystąpienia nie powinien być dokonywany w tym samym dniu, w którym osoba chcąca wystąpić z Kościoła zgłasza swój zamiar duszpasterzowi, ale dopiero po upływie czasu, jaki proboszcz roztropnie pozostawi do namysłu zainteresowanemu ${ }^{34}$. Proboszcz ma również obowiązek poinformować o kanonicznych skutkach karnych formalnego aktu wystąpienia z Kościoła, a więc przede wszystkim o karze ekskomuniki latae sententiae, którą zaciąga odstępca ${ }^{35}$, a której skutkami są: niemożność sprawowania i przyjmowania sakramentów oraz sprawowania sakramentaliów; zakaz udziału ministerialnego w obrzędach kultu; zakaz wykonywania funkcji w Kościele, takich m.in. jak chrzestnego, świadka bierzmowania, świadka zawarcia małżeństwa, przynależności do publicznych stowarzyszeń, ruchów i organizacji kościelnych i katolickich oraz

\footnotetext{
${ }^{32}$ Tamże, n. 5-6, s. 871-872.

33 Tamże, n. 6-7, s. 872.

${ }^{34}$ Tamże, n. 8, s. 872.

${ }^{35}$ Zob. kan. 1364 § 1 KPK.
} 
pozbawienie pogrzebu kościelnego, a także niepodleganie kanonicznej formie małżeńskiej ${ }^{36}$. Nadto proboszcz ma obowiązek wyjaśnić zainteresowanemu, że chrzest jest wydarzeniem, które nie da się wymazać z historii życia człowieka, dlatego wykreślenie z parafialnej księgi chrztu jest niemożliwe ${ }^{37}$.

Po przeprowadzonej rozmowie duszpasterskiej i poczynionych wyjaśnieniach, a także po zbadaniu dokumentów tożsamości odstępcy i świadków oraz zweryfikowaniu, czy oświadczenie o odstępstwie zawiera wszystkie wymagane dane i informacje, proboszcz potwierdza dokument swoim podpisem i pieczęcią parafialną, umieszczając datę. Uwierzytelnioną kopię tego dokumentu proboszcz ma obowiązek przesłać do kurii biskupiej. Ta, jeśli nie stwierdzi nowych okoliczności, poleca proboszczowi parafii chrztu odstępcy (także w przypadku, gdy odstępstwo nastąpiło $\mathrm{w}$ parafii chrztu) dokonanie stosownego wpisu do parafialnej księgi ochrzczonych. Jeżeli odstępca przyjął chrzest w parafii, która należy do innej diecezji, wówczas kuria biskupia przesyła informację o wystąpieniu z Kościoła do kurii biskupiej chrztu odstępcy. Proboszcz parafii zamieszkania odstępcy ma obowiązek także dokonać odpowiedniego wpisu w kartotece parafialnej. Należy zadbać, aby analogiczny wpis został umieszczony również $\mathrm{w}$ duplikatach ksiąg metrykalnych. Dokumentację całej sprawy, zwłaszcza oryginał oświadczenia odstępcy, należy zachować $\mathrm{w}$ archiwum parafii, $\mathrm{w}$ której dokonany został formalny akt wystąpienia z Kościoła ${ }^{38}$.

Treść wpisu w parafialnej księdze ochrzczonych na marginesie aktu chrztu odstępcy powinna brzmieć: „Dnia... w parafii... formalnym aktem wystąpił(a) z Kościoła katolickiego". Adnotacja ta musi być zawsze umieszczana na świadectwie chrztu, ilekroć będzie wypisywane, gdyż jest $\mathrm{z}$ taką adnotacją jedynym dokumentem potwierdzającym formalny akt wystąpienia z Kościoła $^{39}$.

${ }^{36}$ Osoba która dokonała formalnego aktu odstępstwa z Kościoła, zamierzając zawrzeć małżeństwo ze stroną katolicką, podlega przepisom zawartym w kan. $1071 \S 1$ n. 4 i 5 KPK i 1124, a więc musi otrzymać zgodę ordynariusza na zawarcie małżeństwa. Zob. kan. $316 \S 1 ; 874 \S 1$ n. 4; $893 \S 1$; 915, 1184 § 1, n. 1; 1331 KPK; Por. Konferencja Episkopatu Polski, Zasady postępowania w sprawie formalnego aktu wystapienia z Kościoła..., nr 9-10, s. 873.

37 Tamże, nr 11, s. 873.

${ }_{38}$ Tamże, n. 12, s. 873-874.

${ }^{39}$ Zob. kan. 535 § 2 KPK; Zob. Konferencja Episkopatu Polski, Zasady postępowania w sprawie formalnego aktu wystapienia z Kościoła..., nr 14-15, s. 874. 
W sytuacji gdy do kurii biskupiej lub parafii wpłynie informacja z zagranicy o wystąpieniu z Kościoła dokonanym wobec urzędnika cywilnego, nie odnotowuje się tego faktu w księdze ochrzczonych. Zawiadomienie takie należy jednak - w myśl Zasad postępowania - zachować w archiwum parafii, a przy okazji osobistej rozmowy duszpasterza z osobą, której sprawa dotyczy, należy podjąć tę kwestię z zachowaniem wszystkich wymogów dokumentu Konferencji Episkopatu ${ }^{40}$. Gdy sprawa odstępstwa od Kościoła nastąpiła przed ogłoszeniem omawianego dokumentu i znajduje się $\mathrm{w}$ księdze ochrzczonych stosowna adnotacja o wystąpieniu z Kościoła tych, którzy wobec urzędnika cywilnego zgłosili wystąpienie, tego rodzaju wpisy należy traktować $\mathrm{z}$ należną rozwagą. Jeśli z wiedzy na temat danej osoby wynika, że pomimo złożonej deklaracji nie miała rzeczywistej woli wystąpienia z Kościoła, duszpasterz winien się zwrócić do kurii biskupiej z wnioskiem o anulowanie adnotacji w księdze ochrzczonych. Jeśli sprawa wyniknie przy okazji pogrzebu, można udzielić katolickiego pogrzebu w formie uznanej przez proboszcza, o ile praktyka życia zmarłej osoby pozwala sądzić, że nie miała ona woli zrywania ze wspólnotą Kościoła, lub gdy przed śmiercią dała oznaki pokuty i nawrócenia ${ }^{41}$.

Należy dodać, że ordynariusz miejsca - w myśl dokumentu może zadeklarować zaciągniętą karę ekskomuniki, z zachowaniem odpowiednich, wyżej przytoczonych przepisów prawa kanonicznego (kan. $1364 ; 1342 ; 1717-1728)^{42}$.

W przypadku niebezpieczeństwa śmierci grożącemu odstępcy zakaz przyjmowania sakramentów ulega zawieszeniu. Znajdujący się w takiej sytuacji podlegający karze ekskomuniki może otrzymać sakramentalne rozgrzeszenie, przyjąc namaszczenie chorych oraz przystąpić do Komunii świętej ${ }^{43}$, jeżeli o to dobrowolnie poprosi i okaże postawę nawrócenia.

Watro $\mathrm{w}$ tym miejscu zaznaczyć, iż mimo formalnego wystąpienia z Kościoła, ze względu na to, że sakrament chrztu wyciska na człowieku

40 Tamże, nr 16, s. 874.

${ }^{41}$ Zob. kan. 1184 § 1 KPK; Konferencja Episkopatu Polski, Zasady postępowania w sprawie formalnego aktu wystapienia z Kościoła..., nr 17, s. 874-785.

${ }^{42}$ Tamże, n. 13, s. 874; Por. J. Syryjczyk, Kanoniczne prawo karne..., s. 20-21; tenże, Sankcje w Kościele. Część ogólna. Komentarz, Warszawa 2008, s. 261-264.

43 Zob. kan. 1352 § 1 KPK. 
niezniszczalne i niezatarte znamię oraz duchowy i nieusuwalny znak ${ }^{44}$, a więc trwałą więź ontologiczną z Chrystusem i Kościołem, która nie może zostać umniejszona z powodu jakiegokolwiek aktu lub faktu odstąpienia, istnieje możliwość powrotu odstępcy do wspólnoty wiary i Kościoła. Akt taki nazywany jest abiuracją. Oznacza on „zewnętrzne i zgodne z przepisami prawa wyrzeczenie się błędów w dziedzinie wiary przez tego chrześcijanina, który pragnie być przyjęty do wspólnoty Kościoła"45. Kanoniczne prawo karne mówi nam, że należy wtedy zastosować przepisy kan. 1354-1357 KPK regulujące kwestie ustania i zwolnienia z kar kościelnych ${ }^{46}$. Przy ich aplikowaniu należy jednak dokonać rozróżnienia na apostatę, którego kara (ekskomunika latae sententiae) nie została jeszcze deklarowana ${ }^{47}$, i na apostatę, którego kara została już deklarowana $^{48}$. W obu przypadkach zwolnienie $\mathrm{z}$ tych kar nie jest zastrzeżone

${ }^{44}$ Przez sakrament chrztu, który wywiera niezatarte znamię, należymy na zawsze do Kościoła, a więc teologicznie nie ma właściwie „wyjścia” z Kościoła. Por. Sobór Trydencki, sess. VII, kan. 9, Breviarium fidei, s. 436, n. 217.

${ }^{45}$ P. Pałka, Abiuracja, w: Encyklopedia katolicka, t. I, Lublin 1989, s. 17; zob. szerzej na ten temat P. Sadowski, dz. cyt., s. 254-257.

${ }^{46}$ J. Syryjczyk, Sankcje w Kościele..., s. 291-308.

${ }^{47} \mathrm{~W}$ tym przypadku zwolnić apostatę z ekskomuniki może Biskup Rzymski; ordynariusz miejsca względem podwładnych oraz tych, którzy przebywają na jego terytorium oraz każdy biskup w akcie sakramentalnej spowiedzi (kan. 1355 § 2), kanonik penitencjarz (kan. 508 § 1); każdy kapłan, chociażby nie posiadał uprawnienia do spowiadania, ale tylko względem penitentów znajdujących się w niebezpieczeństwie śmierci (kan. 976), a także spowiednik, jeśli penitentowi trudno jest pozostawać w grzechu ciężkim przez czas konieczny do tego, aby zaradził kompetentny przełożony (kan. 1357 § 1). W ostatnim przypadku spowiednik powinien nałożyć na penitenta obowiązek odniesienia się w ciągu miesiąca, pod groźbą ponownego popadnięcia w karę, do kompetentnego przełożonego bądź do kapłana posiadającego odpowiednie uprawnienia oraz zastosowania się do otrzymanych poleceń (kan. 1357 § 2). Penitent powinien oświadczyć, że odwołuje wszelkie błędy i wyznaje wiarę w to wszystko, co Bóg objawił, a Kościół podaje do wierzenia. Na penitenta nakłada się odpowiednią pokutę i obowiązek naprawienia ewentualnego zgorszenia. Kapłan udzielając absolucji od kary, wypowiada słowa: $\mathrm{Na}$ mocy udzielonej mi władzy uwalniam ciebie z więzów ekskomuniki w Imię Ojca i Syna i Ducha Świętego. Amen. Po zwolnieniu apostaty z kary spowiednik udziela mu rozgrzeszenia. Zob. Obrzędy pokuty, Katowice 1981, s. 195; P. Sadowski, dz. cyt., s. 254-255.

48 Zwolnienia apostaty z ekskomuniki deklarowanej może dokonać: Biskup Rzymski; ordynariusz, który upoważnił trybunał do wymierzenia lub deklarowania kary bądź ją dekretem osobiście lub przez innego wymierzył lub deklarował (kan. 1355 $\S 1$ ); ordynariusz miejsca, na którym przebywa przestępca (kan. 1355 § 1); każdy kałan, chociażby nie posiadał uprawnienia do spowiadania, ale tylko względem penitentów znajdujących się w niebezpieczeństwie śmierci (kan. 976) oraz delegowani przez or- 
Stolicy Apostolskiej ${ }^{49}$. Zwolnienie w zakresie zewnętrznym powinno być udzielone na piśmie, chyba że co innego zaleca poważna przyczyna ${ }^{50}$. Należy również wystrzegać się, co podkreśla prawodawca kościelny, „by prośba o zwolnienie lub samo zwolnienie nie były rozgłaszane, chyba że i o ile jest to potrzebne dla ochrony dobrego imienia winnego lub konieczne do naprawienia zgorszenia" ${ }^{51}$. Ta ostatnia kwestia ma zastosowanie przede wszystkim przy apostazji tajnej, nie zaś publicznej. W myśl przepisów prawa kanonicznego to właśnie ordynariusz miejsca, wziąwszy pod uwagę wszystkie okoliczności miejsca i czasu, decyduje o charakterze i publicznym wymiarze obrzędu abiuracji od ekskomuniki deklarowanej za przestępstwo apostazji. Z dokonanego przyjęcia do wspólnoty Kościoła katolickiego sporządza się protokół w księgach parafialnych ${ }^{52}$.

Zasady postępowania Konferencji Episkopatu Polski - w nawiązaniu do powyższych norm prawnych - wskazują, że w sytuacji kiedy odstępca pragnie powrócić do wspólnoty Kościoła, powinien się zgłosić do swojego księdza proboszcza. Po odbyciu stosownego przygotowania może być ponownie przyjęty do pełnej wspólnoty z Kościołem katolickim. Sprawę taką duszpasterz powinien jednak przedstawić kurii biskupiej. Wtedy to ordynariusz może uwolnić z ciążącej na odstępcy kary ekskomuniki, z zachowaniem przepisu kan. $1357 \mathrm{KPK}$, który zobowiązuje do nałożenia odstępcy pokuty oraz naprawienia przez niego zgorszenia i wyrównania wyrządzonej szkody ${ }^{53}$. Po uwolnieniu z kary kościelnej należy dokonać stosownej adnotacji w księgach metrykalnych. Powracający do pełnej wspólnoty z Kościołem katolickim winien złożyć wyznanie wiary ${ }^{54}$.

dynariusza miejsca (kan. 137). W przedostatnim przypadku ci, którzy wyzdrowieliby, muszą się odnieść w ciągu miesiąca, pod groźbą popadnięcia w karę, do kompetentnego przełożonego (kan. 1357 § 3). Zob. P. Sadowski, dz. cyt., s. 256.

49 Tamże, s. 254.

${ }^{50}$ Kan. $1361 \S 2$ KPK.

${ }^{51}$ Kan. 1361 \& 3 KPK.

${ }^{52}$ P. Sadowski, dz. cyt., s. 257.

${ }_{53}$ Zob. kan. 1357 KPK; por. P. Sadowski, dz. cyt., s. 256.

${ }^{54}$ Można je znaleźć w Obrzędach chrześcijańskiego wtajemniczenia dorostych dostosowanych do zwyczajów diecezji polskich, Katowice 1988, s. 193-203. Zob. Konferencja Episkopatu Polski, Zasady postępowania w sprawie formalnego aktu wystapienia z Kościoła..., nr 18 , s. 875. 


\section{TłO I PRZYCZYNY SPORU I NIEPOROZUMIEŃ WOKÓł APOSTAZJI}

Cała sprawa rozpoczęła się od kilku skarg byłych katolików skierowanych do GIODO na proboszczów, którzy nie chcieli wypisać ich z Kościoła katolickiego bez przeprowadzenia przewidzianej prawem kościelnym procedury. GIODO zwracał się do proboszczów o wyjaśnienia. Proboszczowie odpowiadali, że osoby skarżące wciąż są członkami Kościoła katolickiego, ponieważ nie przeszły kościelnej procedury apostazji określonej w Instrukcji Konferencji Episkopatu Polski z dnia 27 września 2008 r.: Zasady postępowania w sprawie formalnego aktu wystapienia z Kościota $a^{55}$. Jej zastosowanie - w myśl przepisów kościelnych - daje podstawę do wystąpienia wiernego formalnym aktem ze wspólnoty Kościoła. Osoby, które - według ich zdania - porzuciły wiarę katolicką i wystąpiły z Kościoła, bo złożyły oświadczenie woli i wysłały je do proboszcza swojej parafii, nie poddając się jednak procedurze kanonicznej wystąpienia z Kościoła, walczyły, aby Kościół nie przetwarzał ich danych, i żądały, żeby dokonano adnotacji o apostazji w akcie chrztu. Proboszczowie tego nie robili, gdyż są zobowiązani stosować przepisy prawa kanonicznego co do wystąpienia z Kościoła formalnym aktem. Apostaci zarzucali więc, że Kościół mnoży im trudności przy wystąpieniu z Kościoła oraz mimo uznania wystąpienia przetwarza ich dane osobowe. Swe skargi (od $2010 \mathrm{r}$. wpłynęło ich 83) wnosili do GIODO.

W sytuacji kiedy osoby pragnące wystąpić z Kościoła nie przeszły procedury kanonicznej wystąpienia z Kościoła formalnym aktem, a tylko złożyły lub wysłały podpisane oświadczenie woli do swego proboszcza, GIODO umarzał sprawy, uznając, że nie ma prawa do wydania merytorycznej decyzji co do wypisania wiernego z Kościoła, a może to uczynić tylko Kościół. Ustawa bowiem o ochronie danych osobowych z dnia 29 sierpnia 1997 r., zmieniona 25 sierpnia 2001 r. ${ }^{56}$ mówi, że GIODO w odniesieniu do zbiorów danych dotyczących osób należących do Kościoła lub innego związku wyznaniowego nie ma uprawnień wydawania decyzji czy prowadzenia inspekcji.

Decyzja GIODO umarzająca sprawy co do dokonania adnotacji aktu apostazji w księdze chrztu ze względu na brak spełnienia wymogów kanonicznych wystąpienia z Kościoła powodowała, że osoby, które nie

${ }^{55}$ Konferencja Episkopatu Polski, Zasady postępowania w sprawie formalnego aktu wystapienia z Kościoła..., s. 870-876.

${ }^{56}$ Dz.U. z 1997 r. Nr 133, poz. 883, z późn. zm. 
miały zamiaru się poddać procedurze kościelnej apostazji i nie zgadzały się $\mathrm{z}$ takim rozstrzygnięciem, składały skargi do sądu, twierdząc, że nie dotyczy ich ten przepis, ponieważ już wystąpiły z Kościoła poprzez złożenie swego oświadczenia, o czym powiadomily swego proboszcza. O ile w pierwszej instancji Wojewódzki Sąd Administracyjny w Warszawie podtrzymywał decyzję GIODO, to już NSA się z nimi nie zgodzili57. I tak w październiku 2013 r. NSA wydał serię orzeczeń, w których uznał, że GIODO nie może z góry umarzać postępowań w sprawie osób, które domagają się wpisu w księdze chrztów o tym, że wystąpiły z Kościoła. Według orzeczenia Sądu GIODO powinien najpierw ocenić, czy takie osoby skutecznie wystąpiły z Kościoła, a więc czy ktoś jest, czy nie jest członkiem Kościoła lub związku wyznaniowego. Orzeczenie sądowe nie wspomina tutaj o roli czy zastosowaniu procedury kanonicznej przy wystąpieniu wiernego z Kościoła. Nakazanie zaś GIODO ocenienia i rozstrzygnięcia, czy ktoś jest członkiem Kościoła, czy nie jest wydaje się że niezrozumiałe i niemające podstaw prawnych, gdyż tworzenie reguł zarządzających wystąpieniem osób z Kościołów i związków wyznaniowych nie mieści się $\mathrm{w}$ zakresie zadań i kompetencji organu ochrony danych osobowych. Raczej orzeczenie NSA winno sugerować ustanowienie nowych uregulowań prawnych.

Jak uzasadniała niedawne orzeczenie NSA sędzia Małgorzata Jaśkowska, „stosunki między związkiem wyznaniowym a państwem regulowane są na zasadach poszanowania ich autonomii oraz wzajemnej niezależności”, ale jednocześnie stwierdziła, że „związki wyznaniowe podlegają jednak przepisom prawa powszechnego, a autonomia [Kościołów] nie może być rozumiana jako pozbawienie państwa jego immanentnej cechy, jaką jest suwerenność”. Dlatego „wystąpienie z Kościoła katolickiego - dopowiedziała - powinno być rozpatrywane na gruncie prawa powszechnego, gdyż dotyczy wolności sumienia i wyznania oraz danych osobowych". NSA stwierdził ponadto, że "GIODO, oceniając to, czy dana osoba wystąpiła z Kościoła czy nie, nie musi kierować się wewnętrznymi przepisami Kościoła, a więc przepisami Instrukcji Episkopatu z 27.09.2008 r., ale sam powinien ocenić to, czy ktoś jest, czy nie jest członkiem Kościoła lub związku wyznaniowego"58.

${ }^{57}$ Zob. http://orzeczenia.nsa.gov.pl/cbo/search.

${ }^{58}$ http://www.deon.pl/religia/kosciol-i-swiat/z-zycia-kosciola/art,17206,giodo-nakazal-odnotowanie-apostazji.html; zob. T. P. Terlikowski, Komu pozwolq być katolikiem, „Do Rzeczy” nr 4/052 (2014), s. 60-61. 
Czy jednak GIODO ma instrumenty i przepisy, aby takie postępowanie przeprowadzić w sposób kompetentny i stwierdzający, czy faktycznie dana osoba ma pełną wolę wystąpienia z Kościoła czy związku wyznaniowego?

W orzeczeniu znajdujemy też zdanie, że „autonomia Kościołów nie zwalnia państwa od obowiązku dbania, by Kościoły nie naruszały konstytucyjnych praw". W tym przypadku chodzi o prawo do prywatności i tzw. autonomię informacyjną, czyli prawo decydowania i kontrolowania, kto i jakie dane o nas zbiera i co z nimi robi. NSA stwierdził, że Kościoły są autonomiczne, jeśli chodzi o własnych członków. Natomiast państwo - a konkretnie GIODO - ma obowiązek chronić dane osób, które wystąpiły z Kościoła ${ }^{59}$.

Czy zatem przytoczona i omówiona wyżej kanoniczna procedura wystąpienia z Kościoła formalnym aktem wymagająca, aby oświadczeniu woli wystąpienia towarzyszyła wewnętrzna wola katolika składającego takie oświadczenie, nie obowiązuje wiernego, który występuje z Kościoła? Przecież akt władzy państwowej nie może decydować o tym czy ktoś jest członkiem Kościoła, czy też nie. W myśl przepisów kanonicznych skuteczność wystąpienia z Kościoła uzależniona jest od przejścia całej kościelnej procedury wystąpienia z Kościoła ${ }^{60}$.

Występujący z Kościoła czy też zwolennicy apostazji zarzucają Kościołowi - co pośrednio wybrzmiewa z orzeczenia NSA - że „łamie prawa człowieka” i "narusza konstytucyjne prawa obywatela” oraz "odbiera im prawa do decydowania o własnym życiu”, gdyż nie usuwa ich danych osobowych z kościelnej ewidencji. Otóż apostazja jest bardzo poważną decyzją mającą skutki prawne. Dlatego Kościół traktuje ją z wielką powagą i wskazuje, że apostazja nie jest możliwa bez wcześniejszego wstąpienia do Kościoła, a więc faktu chrztu i informacji o tym, że miał on miejsce. Sakrament chrztu zaś - jak wspomniano - wyciska na człowieku niezniszczalne znamię i znak oraz trwałą więź ontologiczną z Chrystusem i Kościołem, która nie może zostać umniejszona z powodu jakiegokolwiek aktu lub faktu wystąpienia z Kościoła. Chrzest jest też faktem historycznym, dlatego też wykreślenie z księgi chrztów nie jest możliwe. Ustawa o ochronie danych osobowych z 29 sierpnia 1997 r.

${ }^{59}$ http://gosc.pl/doc/1752740.Kolejne-wyroki-NSA-dot-apostatow.

${ }^{60}$ Zob. J. Gręźlikowski, Apostazja - konsekwencje prawno-duszpasterskie, „Homo Dei" 79(2010), nr 1, s. 68-80. 
nie ma w tym przypadku zastosowania ze względu na postanowienia Konkordatu $^{61}$.

Jeśli więc dana osoba występuje z Kościoła, przy jej nazwisku w akcie chrztu zamieszcza się odpowiednią adnotację, że fakt apostazji miał miejsce. Jest to respektowanie ze strony Kościoła czyjejś decyzji o wyrzeczeniu się wiary, co winno być odnotowane, a tym samym wskazuje, że dana osoba nie jest już członkiem wspólnoty Kościoła. Nie można zaś zupełnie anulować aktu chrztu osoby występującej z Kościoła i wszelkich śladów w ewidencji kościelnej. To tak jakby ktoś zmieniał obywatelstwo. Jeśli jakaś osoba uzna, że chce zmienić obywatelstwo, to w społeczeństwach demokratycznych ma do tego prawo. Nie może jednak domagać się od państwa, z którego „odchodzi”, wymazania nazwiska z ewidencji urzędniczych. W tych przypadkach apostaci nie obwiniają urzędników państwowych o zamach na swoje prawa obywatelskie ${ }^{62}$.

\section{REPERKUSJE I SKUTKI ORZECZENIA NSA I DECYZJI GIODO}

Orzeczenie NSA spowodowało, że GIODO, tam gdzie nie ma wątpliwości, że dana osoba wystąpiła z Kościoła lub związku wyznaniowego, wydaje pierwsze decyzje (wydał ich jak dotąd już pięć) nakazujące proboszczom dokonanie odpowiedniego wpisu w kościelnej księdze chrztu o akcie apostazji, z pominięciem kanonicznej procedury wystąpienia z Kościoła, którą nakazuje wewnętrzne prawo Kościoła (instrukcja Konferencji Episkopatu Polski).

Orzeczenie NSA stwierdzające, że wystąpienia z Kościoła można dokonać w oparciu o przepisy prawa cywilnego i na podstawie czyjegoś aktu woli, z pominięciem określonej procedury kościelnej, budzi niepokój, zamieszanie i niezrozumienie, gdyż stanowi ewidentną ingerencję przepisów prawa polskiego w wewnętrzne prawo kościelne, procedur świeckich w administrację kościelną, jak to powiedział ks. Józef Kloch,

${ }^{61}$ Dane zawarte w księgach metrykalnych, jako udokumentowanie przyjętych sakramentów, są niezbędne do wykonywania własnych zadań Kościoła. Dz.U. z 1997 r. Nr 133, poz. 883 z późn. zm.; E. Kulesza, Ochrona danych osobowych a wolność sumienia i wyznania w prawodawstwie polskim, [w:] Ochrona danych osobowych i prawo do prywatności w Kościele, red. P. Majer, Kraków 2002, s. 12-13.

${ }^{62} \mathrm{http}: / /$ www.deon.pl/religia/kosciol-i-swiat/komentarze/art,858,urojone-problemy-apostatow.html. 
rzecznik Episkopatu Polski ${ }^{63}$. Orzeczenie Sądu oraz pierwsze decyzje GIODO nakazujące proboszczom odnotowanie $\mathrm{w}$ kościelnej księdze chrztu faktu wystąpienia z Kościoła świadczą o tym, że sąd nie uznaje wewnętrznego prawa Kościoła, a tym samym ingeruje w wewnętrzne jego sprawy. Stąd można się zastanawiać, co zapewne będzie przedmiotem dociekań i ekspertyz prawników, czy nie zostały naruszone w ten sposób Konstytucja czy Konkordat. Już stwierdzają oni, jak np. ks. prof. Wojciech Góralski - wybitny kanonista i znawca prawa konkordatowego, „że najwyraźniej NSA nie rozumie arbitralności, suwerenności i gwarancji, jakie posiada Kościół katolicki". Stwierdza on, że NSA rozpatrując sprawę skarg w sprawie apostazji, nie wziął pod uwagę procedur kościelnych i uznał, że ten, kto chce wystąpić z Kościoła, nie musi przestrzegać prawa obowiązującego w Kościele, a przecież jest do tego zobowiązany. Dodał nadto, że „każdy kto ingeruje w wewnętrzne sprawy Kościoła, zwyczajnie łamie Konkordat, a on przecież reguluje stosunki państwo-Kościół"64.

Inny wybitny znawca prawa konkordatowego, ks. prof. Józef Krukowski mówi wprost: „księża nie mogą wykonać nakazów, jakie otrzymali od GIODO, gdyż żaden proboszcz nie ma takich kompetencji. Kapłani bowiem muszą działać zgodnie z prawem kościelnym, a ono dokładnie mówi o tym, co członek Kościoła musi zrobić, aby dokonać aktu apostazji. Wykreślenie wiernego ze wspólnoty Kościoła bez zachowania kościelnych procedur jest nielegalne" ${ }^{\prime \prime 5}$. Dodaje jednocześnie, że „żaden urząd nie może nakazywać duchownym działania, które jest niezgodne z prawem kanonicznym, a więc NSA i GIODO nie mają kompetencji do wydawania decyzji dotyczących ingerencji w księgach kościelnych. Jeżeli takie orzeczenie i nakazy podjęły, łamią Konkordat i Konstytucję RP"66.

Opisane orzeczenia NSA i decyzje GIODO oznaczają ni mniej, ni więcej - że państwo uznało się za władne i kompetentne ingerować w tak oczywiste prawo autonomicznej i równoprawnej wobec niego instytucji, jaką jest Kościół katolicki i członkostwo w nim. A przecież - jak uważa konstytucjonalista z KUL dr Przemysław Czarnek - „nie ma wątpliwo-

${ }^{63}$ http:/ / wiadomosci.dziennik.pl/wydarzenia/artykuly/448181,nasz-dziennikgiodo-narusza-konkordat.html?utm_source=feedburner\&utm_medium=feed\&utm_campaign=Feed:+Dziennik-PL+(RSS+-+Dziennik).

${ }^{64}$ J. Stróżyk, Spór o apostazję, „Przewodnik Katolicki” nr 4 (2014), s. 17.

${ }^{65}$ http://www.naszdziennik.pl/wp/65400,to-byloby-nielegalne.html.

${ }^{66}$ Tamże. 
ści, że do zakresu działalności Kościoła należy właśnie rejestrowanie wiernych i również odnotowywanie tego rodzaju sytuacji, czynności jak właśnie apostazja. To jednak Kościół ze swoim porządkiem prawnym decyduje o tym, czy ta apostazja rzeczywiście nastąpiła, czy nie, czy rzeczywiście mamy do czynienia z faktycznym i rzeczywistym wystąpieniem z Kościoła. Jest to ewidentnie porządek prawa kanonicznego. $\mathrm{W}$ tym zakresie prawo państwowe i państwo nie powinny ingerować $\mathrm{W}$ te procesy" ${ }^{\prime \prime}$.

Interpretując orzeczenie NSA, można też powiedzieć, że Kościół w jego świetle przestał być wobec państwa instytucją autonomiczną, gdyż prawo państwowe może ingerować $\mathrm{w}$ jego sprawy sakramentalne i administracyjne i określać jego procedury odnoszące się do apostazji. Według decyzji sądu nie Kościół ma decydować, kto jest, a kto nie jest jego członkiem, kto wystąpił z Kościoła formalnym aktem, a kto popełnił apostazję, a decyzja GIODO. Jest to nie do przyjęcia w aktualnie obowiązującym porządku prawnym, a więc w świetle przepisów Konstytucji i Konkordatu. Nadto należy zauważyć, że duszpasterze nie mogą się zastosować do tej decyzji NSA i GIODO, gdyż kwestia zapisów w księgach metrykalnych (w tym w księdze chrztów), jakich dokonują proboszczowie, jest obwarowana ścisłymi przepisami prawa kanonicznego. Tak więc do księgi chrztów księża mogą wpisać tylko to, na co zezwala im prawo kościelne. Wprowadzając zaś pewne zmiany (np. zmiana nazwiska w akcie chrztu), proboszcz musi mieć zgodę kompetentnej władzy kościelnej. Interwencja władz świeckich, w tym wypadku GIODO, w dokumenty kościelne, która nakazuje proboszczom dokonywanie wpisów o akcie apostazji w księdze chrztów, jest poważnym nadużyciem. Co więcej, w przypadku apostazji obowiązują - jak wskazano - odpowiednie przepisy kościelne, które są obowiązujące w Kościele i należy je stosować.

Należy też zauważyć, że orzeczenie NSA i postępowanie GIODO powoduje, że proboszczowie znaleźli się w pułapce i mają wielki dylemat i problem, jak postępować. $Z$ jednej strony obowiązują ich przepisy prawa kanonicznego, a więc Instrukcja Episkopatu Polski określająca zasady postępowania w sprawie formalnego aktu wystąpienia z Kościoła oraz zgoda kompetentnej władzy kościelnej na dokonanie zmian w akcie chrztu, a z drugiej strony decyzja GIODO nakazująca im dokonania wpisu do księgi chrztów o akcie apostazji na podstawie tylko aktu woli

${ }^{67}$ J. Stróżyk, dz. cyt., s. 17. 
występującego z Kościoła traktowanego według prawa państwowego. Można powiedzieć, że nie mają podstawy kanonicznej do wypełnienia zadania, jakie stawia przed nimi GIODO. Co więcej, za niewykonanie poleceń GIODO grożą poważne sankcje. Jest to 10 tys. złotych - w stosunku do osoby fizycznej, i maksymalnie 50 tys. złotych - w stosunku do osób prawnych. Jednocześnie grzywny nakładane wielokrotnie nie mogą łącznie przekroczyć kwoty 50 tys. złotych dla osób fizycznych, a w stosunku do osób prawnych i jednostek organizacyjnych nieposiadających osobowości prawnej kwoty 200 tys. złotych ${ }^{68}$. Jak zatem mają postępować proboszczowie? Jak wspomniano na wstępie, Sekretarz generalny Episkopatu Polski bp Wojciech Polak zaleca, , ,aby w przypadku nakazów, które wydał GIODO, każdy z proboszczów odmówił ich przyjęcia i odwołał się od tych decyzji. W następnym kroku proboszcz powinien decyzję odnotowania apostazji w księdze chrztów zaskarżyć do NSA"69.

Takie rozstrzygnięcie i podejście NSA ewidentnie narusza autonomię Kościoła i związków wyznaniowych, jest niezrozumiałe i nie do przyjęcia przez Kościół. Powoduje też wielkie zamieszanie i narusza obowiązujący w Polsce porządek prawny. Nie może bowiem być tak, iż sąd świecki ingeruje w wewnętrzne sprawy i życie Kościoła, że władza świecka, w tym przypadku GIODO, może decydować o tym, kto nie jest członkiem Kościoła, kto nim jest, a kto ma nim zostać, posługując się zasadą, że związki wyznaniowe podlegają przepisom prawa państwowego i muszą się nimi kierować.

Kościół na takie stawianie sprawy, a więc ingerencję władz i procedur świeckich w administrację kościelną nie może się oczywiście zgodzić, jak to napisał na Twitterze ks. Józef Kloch, rzecznik Konferencji Episkopatu Polski. A kanoniści ostro i jednoznacznie odrzucają tego typu decyzje, określając je mianem ingerencji sądu świeckiego w wewnętrzne życie i działalność Kościoła. Orzeczenie NSA nazywają kuriozalnym i wskazują, że jest ono wyjściem poza kompetencje NSA, bo ten nie ma kompetencji zajmowania się administracją kościelną, lecz jedynie państwową, a działanie GIODO na podstawie tego orzeczenia jest złamaniem zasad Konstytucji RP i Konkordatu ${ }^{70}$. Nie może być bowiem tak, że państwo staje się zwierzchnikiem Kościoła, a także strażnikiem jego doktryny oraz

\footnotetext{
${ }^{68}$ Tamże, s. 16.

69 Tamże.

${ }^{70}$ T. P. Terlikowski, dz. cyt., s. 61.
} 
wewnętrznego prawa i decydować o tym, jak winna wyglądać procedura odstępstwa od wiary i wystąpienia z Kościoła. Jeżeli GIODO, w związku $\mathrm{z}$ orzeczeniem NSA, ma problem $\mathrm{z}$ ustaleniem faktu apostazji i decyzją dotyczącą ingerencji w księgach kościelnych, niech zwróci się do Sejmu i do rządzących, żeby zmieniono uzgodnienia, jakie do dziś obowiązują w stosunkach państwo-Kościół.

Należy mieć nadzieję, że po zaskarżeniu decyzji w sprawie odnotowania apostazji NSA - jak powiedział bp. Wojciech Polak - zmieni zdanie i swoją decyzję uzna za błąd. Kościół jednocześnie podejmie zapewne działania, aby sprawdzić, czy NSA nie naruszył Konstytucji RP i Konkordatu.

Niedawne orzeczenie NSA w sprawie apostazji polecające GIODO wydanie proboszczom nakazu odnotowania w kościelnych księgach chrztu aktu apostazji osób, które wystąpiły z Kościoła formalnym aktem, wywołuje zamieszanie, zdziwienie i rodzi niepokój w kręgach kościelnych. Powoduje bowiem, że może nastąpić wystąpienie z Kościoła i odnotowanie tego faktu w parafialnej księdze chrztów przez duszpasterza nie na podstawie określonego przez Konferencje Episkopatu Polski postępowania kanonicznego, ale na podstawie decyzji i nakazu GIODO skierowanego do proboszcza. Tym samym zostaje wprowadzona nowa, świecka procedura aktu apostazji odnoszącego się do wystąpienia z Kościoła, o której decydować będzie GIODO, a nie określona prawem procedura kościelna. Ta zmiana, która wynika i którą chce wprowadzić w życie orzeczenie NSA, powodująca zmianę dotychczasowego postępowania w odniesieniu do osób, które pragną wystąpić z Kościoła, deprecjonuje i wchodzi w dotychczasowe kompetencje procedur kościelnych. Stanowi więc ewidentne zagrożenie suwerenności i autonomii Kościoła, gdyż jest ingerencją procedur świeckich $\mathrm{w}$ administrację kościelną. Pozwala organom państwowym, w tym przypadku decyzjom GIODO, ingerencję w dokumenty kościelne oraz orzekanie, kto wystąpił z Kościoła, a kto nie, poprzez sprawdzanie skarg osób, które wystąpiły z Kościoła.

Decyzje NSA i GIODO spowodowały, że powstało zamieszanie wokół apostazji - odstępstwa od wiary i Kościoła oraz postępowania kościelnego w sprawie formalnego aktu wystąpienia z Kościoła i zapisania tego faktu w księdze chrztu osoby dokonującej tego aktu. Wspomniane decyzje wskazują, że sprawę apostazji, czyli odejścia, wystąpienia z Kościoła, mogą regulować przepisy prawa państwowego, a nie kościelne, 
jak to było dotychczas, a Kościół - w zakresie własnej sakramentologii i stosowania swojego wewnętrznego prawa - może podlegać decyzjom państwa. Jest to sytuacja kuriozalna, naruszająca obowiązujący stan prawny w Polsce, a szczególnie Konstytucję RP i Konkordat. Należy mieć nadzieję, że zaskarżanie przez proboszczów decyzji GIODO nakazującej im odnotowanie w kościelnych księgach chrztu aktu apostazji do NSA pozwoli raz jeszcze wyjaśnić sprawę dokładnie i wnikliwie oraz zgodnie z obowiązującym prawem, które pozwala Kościołowi kierować się swoim wewnętrznym prawem, a tym samym aprobuje suwerenność i autonomię Kościoła.

Słowa kluczowe: apostazja, odstępstwo od wiary i Kościoła, procedura wystąpienia z Kościoła, orzeczenie Naczelnego Sądu Administracyjnego w sprawie apostazji.

Abstract. Controversy about the apostasy of faith and church. A recent ruling of the Supreme Administrative Court (NSA) on the apostasy of recommendation to the Chief Inspector for Personal Data Protection (Inspector) edition pastors order recorded in the church books of the baptism act of apostasy that occurred from the Church by a formal act, causes confusion, surprise and raises concern in ecclesiastical circles. Causes fact, that may be an instance of the Church and note this fact in the book of baptisms for the parish priest not on the basis determined by the Conference of the Polish Episcopate canonical proceedings, but on the basis of the decision and order of the Inspector General. Thus is launched a new, secular act of apostasy procedure relating to the occurrence of the Church, which will be determined by the Inspector General, and not a particular procedure Church. This change introduced by the ruling Supreme Administrative Court, will replace the existing procedure for persons who wish to withdraw from the Church and undermines existing procedures Church in this regard. It is therefore a threat to the sovereignty and autonomy of the Church, as is evident interference with the procedures of the laity in the Church administration. It allows state authorities, in this case the decisions of the Inspector General, interference in church documents and adjudicate who performed an act of apostasy from the Church.

Decisions of the Supreme Administrative Court and the Inspector General made the confusion arose around the apostasy - deviations from the faith and of the Church and ecclesiastical proceedings on the formal act of the Church and save this fact in the book of the baptism of the person making the act. These decisions indicate that the matter of apostasy, may regulate the law of the state, not the church, as it was previously, and the Church - in terms of their own sacramental and use its internal law - may be subject to decisions of the state. It is a bizarre situation, violating the applicable legal situation in Poland, especially the Constitution and the Concordat. It is hoped that pastors to challenge the decision of the 
Inspector General ordering them recorded in the church books of the baptism act of apostasy, the NSA will once again clarify the matter thoroughly and carefully and in accordance with applicable law, which enables the Church to be guided by its internal law, and thus approves of sovereignty and autonomy of the Church.

Keywords: apostasy, apostasy from the faith and the Church, the procedure of the onest of the Church, the Supreme Administrative Court ruling on apostasy. 